Oleksii Dotsenko, Rostislav Lutsenko, Olena Ivankina

V.N. Karazin Kharkiv National University

4 Svobody Sq., 61022, Kharkiv, Ukraine

E-mail: dotsenko9999@ukr.net, roxanisen@gmail.com, elena0ivankina@gmail.com

ORCID: https://orcid.org/0000-0003-0737-3902

\title{
INVESTMENT ANALYSIS OF THE WORLD'S LARGEST PRODUCER IN FOOD AND BEVERAGES SECTOR
}

The assessment of the financial appeal of investments in stocks and securities is carried out by large specialized firms, but the public information on joint-stock giants is accessible to everyone, so why can no one predict the further course of events in the market? Using the methods of quantitative analysis, it is possible to make an independent forecast of the share prices movement at least for 5 years ahead. The article presents a comprehensive financial and investment analysis of the world's largest food producer using specialized methods for evaluating and comparing businesses.

The investment appeal of the international food company Nestlé is examined, using mathematical methods of economic investment analysis. The result of the study is a short term growth forecast, which can be used for effective investment activity. A comprehensive analysis of the company's activities across all product verticals is carried out, the main dominant and most promising sectors are identified. Besides, financial indicators are predicted and estimated, including those of organic growth, margin, and EBITDA. The dynamics of the balance and changes in cash flow are also analyzed. Using such valuation methods as DiscountedCashFlow, Asset Pricing Model and WACC Calculation, three scenarios of the of Nestle shares movement in the stock market are developed.

Our conclusions show, that the company's activities are characterized by: a slow but steady financial growth, artificial redemption of shares to stimulate price growth, market oversaturating with competitors, overpriced stock, a wide variety of portfolio companies.

Our research allows us to determine the investment attractiveness of the shares and recommend holding shares. Industry dynamics exceeds the Group's reaction and the company's shares are overvalued. In addition, Nestle has a powerful long-term revenue growth potential, which is confirmed by our calculations.

Key words: WACC calculation, financial analysis, DCF model, cost of equity, investment analysis.

JEL Classification: F21, G32, F24, R42, G17.

О.В. Доценко, Р.Р. Луценко, О.В. Іванкіна

Харківський національний університет імені В. Н. Каразіна пл. Свободи, 4, м. Харків, 61022, Україна

E-mail: dotsenko9999@ukr.net, roxanisen@gmail.com, elena0ivankina@gmail.com ORCID: https://orcid.org/0000-0003-0737-3902

\section{ІНВЕСТИЦІЙНИЙ АНАЛІЗ НАЙБІЛЬШОГО В СВІТІ ВИРОБНИКА ПРОДУКТІВ ХАРЧУВАННЯ}

Оцінкою фрінансової привабливості інвестицій в акції та цінні папери займаються великі спеціалізовані фрірми. Однак публічна інформація акціонерних гігантів доступна кожному. Чому ж тоді ніхто не може передбачити подальший хід подій на ринку? За допомогою методів кількісного аналізу можливо самостійно реалізувати розрахунки щодо прогнозу руху цін акцій як мінімум на наступні 5 років. Ми вирішили провести комплексний фінансовий та інвестиційний аналіз найбільшого у світі виробника продуктів харчування, використовуючи спеціалізовані методи оцінки та порівняння підприємств.

В роботі ми розглянули інвестиційну привабливість міжнародної продуктової компанії Nestle за допомогою математичних методів економічного інвест-аналізу. Результатом дослідження $є$ прогноз зростання в короткостроковій перспективі, який може бути використаний для ефрективної інвестиційної діяльності. Був здійснений комплексний аналіз діяльності фірми по всіх вертикалях, виділені головні домінуючі та найбільш перспективні галузі. Окремо були спрогнозовані фрінансові показники органічного зростання, маржі і EBITDA. Так само було проаналізовано динаміку балансу і змін в русі грошових потоків. На основі таких оціночних методів як Discounted Cash Flow, модель ціноутворення основних засобів та розрахунок WACC, розроблені три сценарії розвитку позиції акцій Nestle на ринку цінних паперів.

\footnotetext{
${ }^{\odot}$ Dotsenko O.V., Lutsenko R.R., Ivankina O.V., 2019
} 
На підставі проведеного аналізу можна зробити наступні висновки щодо діяльністі компанії: спостерігається повільний, але впевнений фрінансовий ріст, для стимуляції росту акції курсу використовується їх штучне викуповування, ринок перенасичений конкурентами, ціна акцій завищена, портфель форми диверсифікований

Отже, в рамках нашого дослідження, вдалося визначити інвестиційну привабливість акцій Nestle i рекомендувати тримати акції. Динаміка промислового виробництва є швидша, ніж Група може реагувати, і акції компанії переоцінені. Крім того, Nestle має потужний потенціал довгострокового зростання доходів, що підтверджується приведеними у роботі розрахунками.

Ключові слова:, формула WACC, фінансовий аналіз, модель DCF, розрахунок вартості капіталу, інвестиційний аналіз.

JEL Classification: F21, G32, F24, R42, G17.

А.В. Доценко, Р.Р. Луценко, Е.В. Иванкина

Харьковский национальный университет имени В. Н. Каразина

пл. Свободы, 4, г. Харьков, 61022, Украина

E-mail: dotsenko9999@ukr.net, roxanisen@gmail.com, elena0ivankina@gmail.com

ORCID: https://orcid.org/0000-0003-0737-3902

\section{ИНВЕСТИЦИОННЫЙ АНАЛИЗ КРУПНЕЙШЕГО В МИРЕ ПРОИЗВОДИТЕЛЯ ПРОДУКТОВ ПИТАНИЯ}

Оценкой финансовой привлекательности инвестиций в акции и ценные бумаги занимаются крупные специализированные фирмы. Однако публичная информация акционерных гигантов доступна каждому. Почему же тогда никто не может предсказать дальнейший ход событий на рынке? С помощью методов количественного анализа возможно самостоятельно осуществить прогноз движения цен акций как минимум на 5-летнюю перспективу. Мы решили провести комплексный фринансовый и инвестиционный анализ крупнейшего в мире производителя продуктов питания, используя специализированные методы оценки и сравнения предприятий.

В работе используются математические методы экономического инвест-анализа для оценки инвестиционной привлекательности международной продуктовой компании Nestle. Результатом исследования является прогноз роста в краткосрочной перспективе, который может быть использован для выработки эффективной инвестиционной политики. Был осуществлен комплексный анализ деятельности фирмы по всем вертикалям, выделены главные доминирующие и наиболее перспективные отрасли. Отдельно были спрогнозированы финансовые показатели органического роста, маржи и EBITDA. Так же была проанализирована динамика баланса и изменения движения денежных потоков. На основе таких оценочных методов как Discounted Cash Flow, модель ценообразования основных средств, расчет WACC, разработаны три сценария развития положения акций Nestle на рынке ценных бумаг.

По итогам работы можно сделать следующие выводы о деятельности компании: наблюдается медленный, но уверенный финансовый рост, для стимуляции роста курса акций производится их искусственный выкуп, рынок перенасыщен конкурентами, цена акций завышена, портфель фирмы диверсифицирован.

Исследование позволило оценить инвестиционную привлекательность акций компании и рекомендовать держать акции. Динамика отрасли быстрее, чем Группа в состоянии отреагировать, $и$ акции компании переоценены. Кроме того, Nestle обладает мощным долгосрочным потенциалом роста выручки, что подтверждается нашими расчетами.

Ключевые слова: формула WACC, финансовый анализ, модель DCF, расчет стоимости капитала, инвестиционный анализ.

JEL Classification: F21, G32, F24, R42, G17.

Statement of the problem. Investment attractiveness rating of joint-stock company is a long and time-consuming procedure. In today's market conditions, it is especially difficult to predict the rate of stocks growth or decline. But with the help of special methods and models such as DCF model and others, this task becomes more feasible. In this paper we will try to make a comprehensive investment analysis on the example of Nestle company, using special methods.

Naturally, the enormous scale of Nestlé complicates the task of day-to-day management and control of the company due to its bureaucratization and multi-layered hierarchy. Thus, the Group loses in flexibility, speed of reaction to changing trends in the market and individualization of approach to each client compared to other, smaller firms. Accordingly, such management problems significantly slow down the growth and subsequent development of the company. 
Analysis of recent studies and publications. The analysis of major industry players is interesting not only to firms-competitors but also to the states (Robinson et.al., 2015), (Demirel et.al., 2011), (Raifeld et.al., 2004). Large-scale analytical studies are conducted in EU countries by EUMERCI organization, which deals with fostering the growth of energy efficiency in EU industry. In its work "Analysis of Food and Beverage Sector in different Countries" the organization makes a comprehensive analysis of the industry relying on geographic specifics. In general, scientific work contributes to quality planning and forecasting (EU-MERCI, 2016).

Such studies were carried out by a group of scientists from Turkey, University of Thrace Economics and Administrative Sciences Department, under the guidance of Metin Atmaca and Engin Demirel (International Journal of Economics and Financial Issues, 2017). 22 food and beverage sector companies traded on the Istanbul stock exchange were selected to be studied within the period of 2008-2015. This research was aimed to investigate the relation between a firm's financial ratios and selected macroeconomic indicators, such as income, poverty, and Gini coefficient value. Time series of financial ratios are obtained from a firm's financial statements.

The team of scientists - Oriol Aluja Méndez, Leah Binsted Castro and Just Gatius Gómez accomplished Nestlé analysis in more detail (Méndez et.al., 2010). The major work "Qualitative and quantitative Nestlé analysis" describes in detail financial aspects of the firm's activities and gives recommendations on how to improve economic performance.

Statement of the objectives of the article. The topic, dealing with the analysis of firms in food and beverages industrial sector may be considered in various aspects. In our work, we decided to analyze the largest company in the sector - Nestle one. The purpose of this article is to analyze the company's financial position and forecast stock prices in order to formulate the recommendations of the investment activity.

The relevance of the work lies in the possibility of practical application of the methods of analyzing the investment attractiveness of a real company. The object of research is Nestle and its investment attractiveness. The subject of the study is the practical use of investment valuation methods on the example of the selected company. The practical significance of the work is that it can be used in further methodological developments or decision making in direct investment activities.

Basic materials presentation.

Robust earnings growth. Stable growth in profit margins is anticipated over the forecasted period. Nestle managed to strengthen its balanced growth model and anchored profitable growth in a sustainable manner in the first half of 2015 . We are confident about the ability of the business to expand sales beyond the existing limits in a period of 3 to 5 years. 2019 should be more successful for Nestlé vs 2018. We also anticipate that the company should finally break the psychological barrier of revenue of 100 billion CHF in the next 5 years. As a result of our investigation, based on the current dynamics of the company's main financial indicators, we are able to claim that annual revenue growth will reach $2 \%$ in 2019 and increase smoothly by 2023 up to $2.5 \%$.

Diversification in the key product. The company's margin improvement reflected the positive contribution of all the segments. Over the past three years, Nestle has experienced a stable increase in earnings stemming from launching the new products and patent extension for existing ones. Nestle has made good progress in the execution of the portfolio management strategy. Nestlé is actively evolving portfolio towards high-growth, high-margin categories that offer differentiation and value creation opportunities.

Nestlé points out 7 core products (Figure 1):

- Powder and liquid beverages;

- Water;

- Milk products and ice cream;

- Nutrition and Health Science;

- Prepared dishes, cooking aids;

- Confectionery;

- Petcare. 


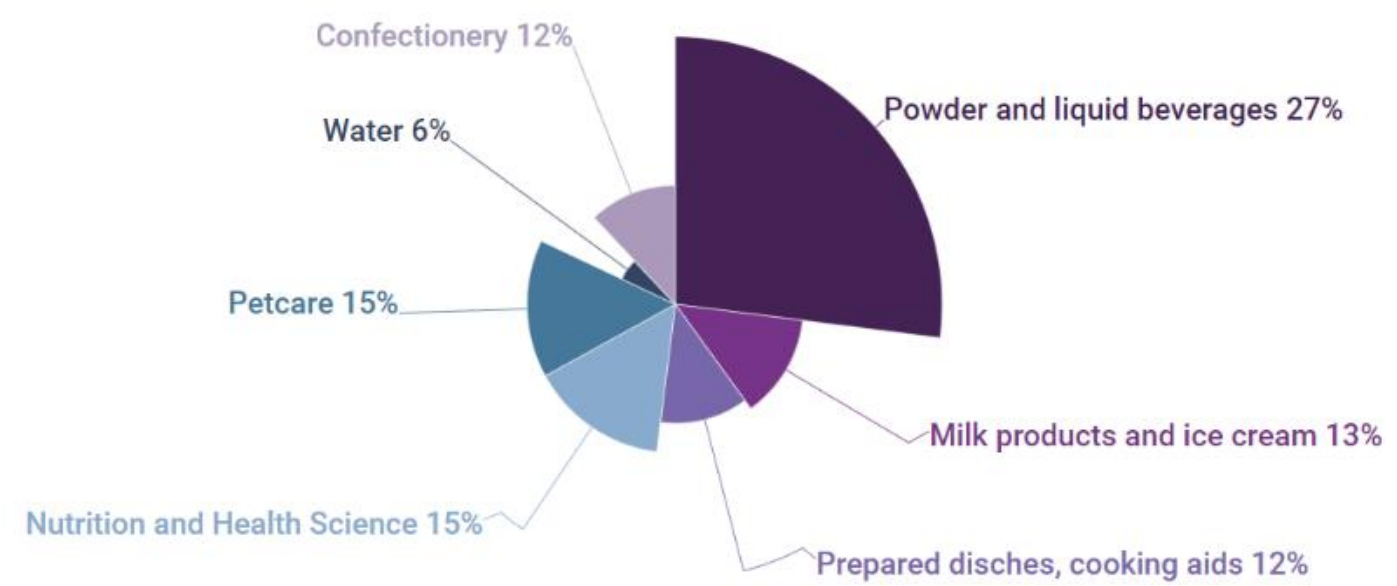

Fig.1. Segments average \% of revenue $(2019 e-2023 e)$

Source: author's development

We highlight three growing leading industries and their expected annual sales growth: Petcare (over $3 \%$ ), Powder and liquid beverages (over 4\%), Nutrition and Health Science (over 3,5\%). During the past five years Nestlé has experienced a stable margin improvement, reflecting high contribution of all the divisions. In general, all Nestlé products are well diversified, which has a positive impact on the manufactured products, markets reorientation and development of new types of products with the aim of increasing the efficiency of production, economic gain and bankruptcy prevention. Thus, we state that Nestlé reduces risks and volatility for capital and assets by investing in various industries. Although it creates a considerable level of uncertainty in stable revenue streams generated in this vertical. We presume, that in the next five years, earnings of Nestle allow to maintain such growth despite of the considerable financial pressure on consumers and fierce competition between food producers.

Profit margins increasing. The main attractiveness of Nestlé for investors is that a shareholder can get low-risk equity with a strong financial background. Earnings performance of the company is stable. Organic growth is projected to remain at $3 \%$ per year. Organic growth will be 1$1.5 \%$ in the developed markets and more than $5 \%$ in the emerging markets. Accordingly, there will be a robust growth of all profitability ratios. Gross profit margin amounts to more than 50\% in 2017 . We also emphasize that this indicator will grow by 2023 up to $52.5 \%$. We expect that EBITDA in 5 years will exceed $16.2 \%$ of revenue and in the future will gradually approach $20.9 \%$ and remain stable. We are convinced that that EBITDA will increase due to the overall growth of sales, interest expenses and taxes. This positive outlook is largely underpinned by the exceptional uniqueness and scale of Nestlé, which is unrivaled.

Profitability. Nestlé has the highest gross margins in food industry. Its $51 \%$ gross margins allow it to invest in advertising and innovation, both of which are key factors for the long-term survival of FMCG companies. However, at the EBIT margin level, the company is below the peer average, with 15\% EBIT margin in 2017. On the whole, company's EBIT margin has stalled in the most recent years, and in 2017 EBIT margin was $14.7 \%$. Input boost pressure and restructuring costs are the main causes of margins stagnation. In September, 2017 Nestlé set the first margin target in its history and started a cost efficiency program with the aim to raise EBIT margins to $18-20 \%$ by 2020 . Hence, judging by the current position, the company is able to achieve this goal.

Cash conversion at Nestlé is below the long-term industry average at $\sim 85 \%$, however, it has improved by $\sim 700$ bps between 2008 and 2018, through working capital efficiencies and a reduction in Capex. We also examine whether operational performance at Nestlé, measured by sales by the factory, reflects improving the efficiency of operational assets.

As for Accounts Receivable and Inventory, according to our hold forecasts, no changes are expected. Indicators will keep proportional growth and will be about $14 \%$ and $10 \%$, respectively. Despite the fact that we forecast an increase in the share of Operating (from $15.8 \%$ to $18 \%$ ) and 
Free Cash Flow (from 11.5\% to 14\%) in sales, Dividend Payout Ratio should be reduced to $~ 72 \%$ without causing damage to dividend yield. Therefore, we see no reason to sell shares.

Debt and divide trend. Historically Nestlé has operated at relatively low leverage. The company leveled up to a peak of 1.5 times Net Debt/EBITDA in 2001 after acquisition of Ralston Purina (Official cite of Nestle company). Since then, the company has been reducing its debt levels, with Net Debt/EBITDA, peaking at 1.4 times in the past 15 years. Nestlé's Net Debt/EBITDA of 1.4 times at the end of 2017 is well below its peer group average of around 3.0 times. Debt is denominated in a broad range of currencies, which helps to diversify Nestlé's financial risk. Nestlé's strong financial position gives it ample flexibility to be a consolidator in consumer products industry.

Nestle has historically spent CHF 1 billion - CHF 3 billion of its roughly CHF 10 billion in annual free cash flow on bolt-on deals (Official cite of The Nielsen Company). The Group has also used cash to repurchase shares in recent years. Nestle generates around CHF 4 billion per year in free cash flow after the dividend having been paid. We assume share buybacks will be financed through long- and short-term debt in equal proportion and Nestle could still deleverage down to 1.2 times Net Debt/EBITDA by fiscal 2023 due to its improved profitability, leaving ample room for large acquisitions.

Positive change in cash flow. Nestle has a strong balance sheet and generates close to CHF 10 billion per year in free cash flow, so capital allocation is one of management's greatest challenges and critical to stock performance. The primary use of the cash windfall generated by the $\$ 28$ billion sales of Alcon to Novartis in 2010 has been share repurchases, with CHF 18 billion used to buy back shares through 2017, and a further CHF 20 billion program announced in 2017 (Official cite of Nestle company).

The positive change in net income from associates reflects acquisitions made in 2016 and 2017 and improvements in net income for some of them. We forecast a free-cash-flow growth of $12 \%$ in 2018 to $14 \%$ by 2023 , supported by sales growth and operating margins, as well as a favorable currency effect. Nestlé has been suffering significant FX headwinds due to the fact that it reports accounts in CHF yet the currency accounts for only $1.4 \%$ of the company's revenues. The continuous appreciation of the Swiss Franc in recent years has translated into a $\sim 34 \%$ headwind between 2010 and 2017. Ideally, investors will benefit the most when the value of their international investment goes up and is paired with a rising currency.

Valuation method and risk statement. Nestlé's profitability is derived from sales to consumers and therefore is subject to variances in consumer income and confidence. As for an international company, its results, reported in Swiss francs, are subject to exchange rate movements. The Group has been actively acquiring and disposing of operations, and in the future further such activity could impact financial performance, both - upside and downside. The declining popularity of confectionery category and competitive pressures are other potential risks.

The Market approach is a business valuation method for determining the value of assets based on the selling price of similar products. In our research the Market approach has $25 \%$ weight, which includes relative public and transaction multipliers, and Discounted Cash Flow (DCF) analysis as an intrinsic value approach with $75 \%$ weight to determine the target share price for Nestlé S.A. Therefore, our valuation arrives at $90.5 \mathrm{CHF}$ target price (figure 2).

DCF model. We consider the price obtained using DCF model to be assigned more weight than due to market approach, which does not exclude short-term distorting market fluctuations. We consider this method to be more fundamental and based on a long-term perspective considering different scenarios.

According to the base 5 -year model, target share price is $95 \mathrm{CHF}$.

Cost of equity calculation. In order to calculate equity cost we use Capital Asset Pricing Model (CAPM). It derives $5.5 \%$ cost of equity including the next indicators:

- Risk-free rate $-1.72 \%$, according to Aswath Damodaran methodology and his "Risk-free Rates based upon Differential Inflation" value;

- Market premium - 5,37\%, Aswath Damodaran, Equity Risk Premium by Country - July 2018;

- Country risk premium - 0,6\%, calculated as weighted average of main countries' risk premiums weighted with $\%$ of sales;

- Beta - 0,6 (that means that the share price will be less volatile than the market).

WACC calculation. To calculate it, we make an assumption that tax rate equals average of the last 7 years $-28.8 \%$. 


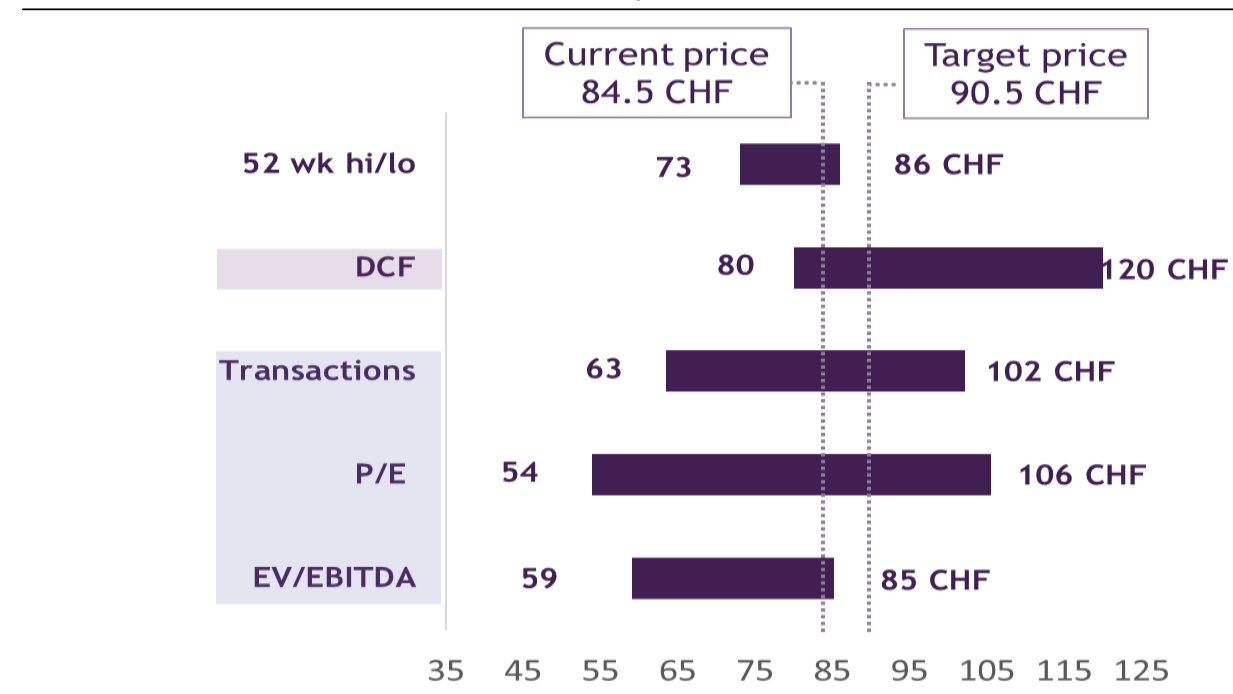

Source: author's development

Fig. 2. Discounted Cash Flow (DCF) analysis

Base, bull and bear cases. The Base case is based on the main forecast values of Revenue growth with 2.5\% CAGR since 2019 till 2023, EBITDA 4.8\% CAGR. We assume that such growth is driven by organic growth of the main product groups. Another key driver of our valuation is a margin. Based on the results, EBITDA margin expansion is to be $18,23 \%$ in 2023 . Unlevered Free Cash Flow CAGR over 2019-2023 years equals $8.6 \%$ (for comparison, CAGR in 2013-2018 is 7.5\%) (World Bank Open Data). The research was conducted using exit multiple approach (EV/EBITDA) to derive PV Terminal Value.

Optimistic case main assumption is Total revenue growth with 4\% CAGR over 2019-2023. This high growth is driven by capturing new gradually gaining demand markets: raw food, sugar- and gluten-free confectionary, organic and non-GMO food ones. Also, it implies the implementation of product and business model innovations, investment in high-growth categories (such as coffee) and regions (emerging markets) Unlevered Free Cash Flow CAGR 2019-2023 - 11.5\%. EBITDA margin is also much higher and equals $20 \%$. It could be reached with a strict cost-cutting strategy, production technology modernization and operating costs lowering.

Indicators in bear case: EBITDA 1.7\% CAGR 2019-2023 and EBITDA margin starting at the lowest (of 2013-2018) level in 2019, reaches 16,4\% (current level) in 2023. Average total revenue growth rate $-1.4 \%$. This is due to a strong impact of the main risks, and competition in the most profitable sectors.

Sensitivity analysis. Sensitivity analysis is conducted with regard to EV/EBITDA and WACC changes, as the decisive factors in price determining. With WACC equal to $4,5 \%$ and EV/EBITDA $19,5 \mathrm{x}$ the highest price reaches $100 \mathrm{CHF}$. This case has a considerable possibility since WACC is dependent on calculation methods and accuracy, for instance, the widely spread approach in CAPM (important WACC's part) calculation is taking government bond yield as a risk-free rate, which significantly lows the WACC value.

Relative Valuation. Using relative valuation method, we've obtained the price of $76.4 \mathrm{CHF}$. This price is a weighted sum of the estimated price by two methods - public and transactional multipliers. Public multipliers consist of an average between the price obtained using EV/EBITDA and P/E multiples (Figure 3).

Public multipliers. A key factor in public multipliers valuation method is the suitable peer group selection. Taking into account a large size of Nestle and diversity of the portfolio, selection of comparable competitors' is difficult (BCG, 2017). For this reason, we considered it to be more accurate to give less weight for the price derived from the Market approach. Of the competing companies reviewed, related to the Packaged Beverages and Soft Drinks industries, only four comparable companies were selected by the criterion of market capitalization closest to Nestle, geographical factor, and related industry: Coca-Cola Co, PepsiCo Inc., Unilever NV, and Mondelez 
International Inc (The portal for statistics, 2018). However, key financial indicators of the chosen companies are widely spread and it can provide a distorting effect. Nestles ROIC is $12.96 \%$, almost equal to the median $12.4 \%$ value. Three-Year Revenue Growth Rate $(0.4 \%)$ is higher than the median value $(-2.55 \%)$, but 3 -Year EPS without NRI Growth Rate $(-19.9 \%)$ is much less than the median (-0.6\%). Three-Year EBITDA Growth Rate (-0.4\%) is also less than the median (3.8\%). All the companies have a similar net margin with a median equal to $10 \%$.

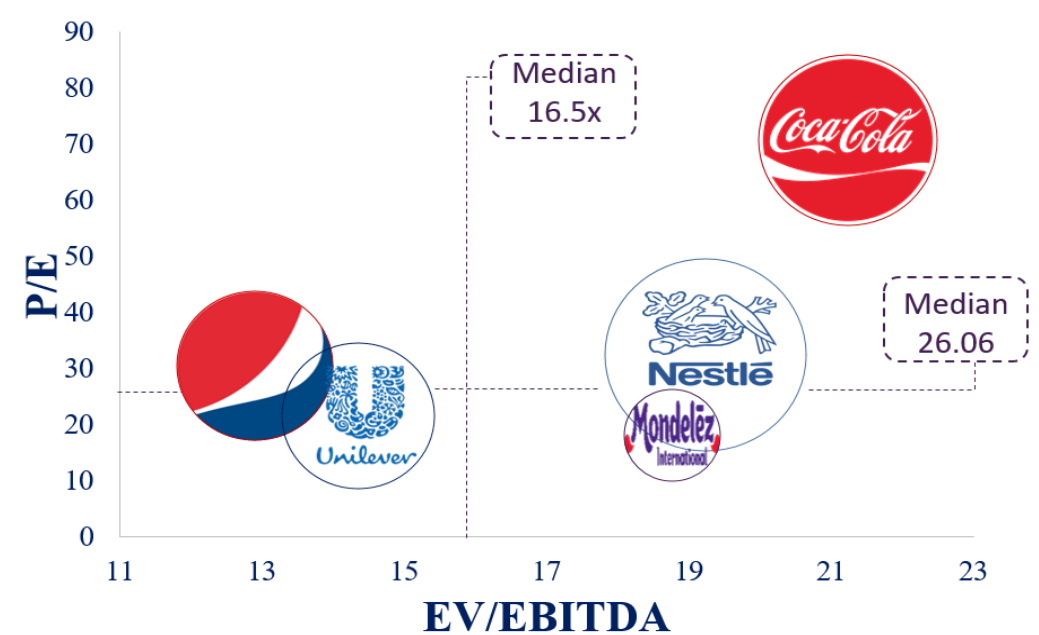

Source: author's development

Fig. 3. Public multipliers

In public multipliers valuation we focused on EV/EBITDA ratio, which is most appropriate for transnational corporations valuation, as it excludes taxes and ignores the effect of individual countries' taxation policies. P/E ratio was chosen as the most popular way to assign a relative value to a stock. The implied price range provided with $\mathrm{P} / \mathrm{E}$, appears the widest price range and the lowest estimated price. It can be explained by the lower EPS Growth Rate against peers and P/E ratio above the median value. The lower price obtained using public multipliers is also due to the fact that in EV/EBITDA and P/E Industry Distribution Nestle SA's respective indicators fall into a $3 Q$, that means a maximum gap.

Transactions multipliers. Despite the fact that this method is less popular than the public multipliers one, we consider it appropriate for estimating the price of Nestlé shares. An integral part of the company's development is a constant review of a brand portfolio and application of strategic mergers and acquisitions (M\&A) opportunities. Thus, application of this method is expedient in terms of valuation of an enterprise and therefore share price as part of a merger/acquisition.

The evaluation presented the transactions of 2014-2018. Geographical distribution of Headquarters - Country (Target/lssuer): 39\% - Zone AMS, 33\% - Zone AOA and 28\% - zone EMENA (Komarist at.al., 2019). Implied Enterprise Value/EBITDA median equal to 18.95x. Average Total Transaction Value -815.62 USDmm. The target price derived by this method is $83,1 \mathrm{CHF}$.

Conclusions. The research has shown that, considering Nestlé's strong balance sheet, stable dividend growth and high profitability margins over the next five years, the company's stock will be an attractive investment for the subject holding period.

It is also necessary to emphasize the influence of the main risk for Nestlé, which is represented by the market, oversaturated with competitors. Intensive competition reveals the weaknesses of the company due to negative scale effect. The Group needs to implement a list of tools specific for smaller firms that contribute to flexible and effective management, as well as accelerating the response to rapidly changing market trends.

Several methods are needed to assess the current situation of Nestlé from different points of view, which in turn improves the quality of the resulting forecasts. We've applied a combination of two basic approaches in order to determine the target price. Discounted Cash Flow analysis as an intrinsic value approach gave a higher value, than the market approach, which includes public and 
transaction multipliers. One of the reasons for our recommendation HOLD is a wide spread between the prices estimated with the use of these methods. The market approach arrives at price that is $10 \%$ lower than the current share price. It can be considered as a sign of overvalued Nestlés share price. More fundamental and long-term perspective based on DCF analysis method (Base case) arrives at $12 \%$ premium estimated price.

In general, as shown by a comparison with the company's reporting, the approach used makes it possible to effectively predict the subsequent vector of the company's development. An important distinguishing feature of the company is slow but stable financial growth, as well as a wide variety of portfolios, which is why the Group is a reliable investment in the long term.

\section{References} Analysis.

1. Robinson, T.R., Henry, E., Pirie, W.L., Broihahn, M.A. (2015). International Financial Statement

2. Demirel, E., Atakisi, A., Atmaca, M. (2011). Financial and economic factors affecting debt ratio and ROE; ISE tourism firms case. European Journal of Scientific Research. 61(3), 458-466.

3. Raifeld, A., Gurfinkel, M., Rao, R., Xi, H., Saxena, S. (2004). An Analysis of the Food and Beverage Industry. Retrieved from people.stern.nyu.edu/adamodar/pdfiles/cfprojs/food.pdf.

4. EU-MERCI: Analysis of Food and Beverage sector in different Countries. Retrieved from http: .www.eumerci-portal.eu/documents/20182/38527/10+-+Other+countries.pdf.

5. International Journal of Economics and Financial Issues (2017). 7(3), 537-541. Retrieved from http://dergipark.gov.tr/download/article-file/365425.

6. Méndez, O.A., Castro, L.B., Gómez, J.G. (2010). Qualitative and quantitative analysis of Nestlé. Retrieved from http: .diposit.ub.edu/dspace/bitstream/2445/

46834/1/Qualitative\%20and\%20Quantitative\%20Analysis\%20of\%20Nest1\%C3\%A9.pdf.

7. Official cite of Nestle company. Retrieved from https: www.nestle.ua.

8. Official cite of The Nielsen Company. Retrieved from https: www.nielsen.com.

9. The portal for statistics. Retrieved from https: www.statista.com.

10. World Bank Open Data. Retrieved from https: data.worldbank.org.

11. Komarist, K.A., Ivankina, O.V., Lutsenko, R.R., Dotsenko, O.V. (2019). Investment analysis of the world's largest producer in food and beverages sector. The Digital economy: models and methods of analysis, 166-168. (In Ukrainian)

12. BCG: How Big Consumer Companies Can Fight Back. Retrieved from https: .www.bcg.com/publications/2017/strategy-products-how-big-consumer-companies-can-fight-back.aspx.

\section{Література}

1. Robinson T.R., Henry E., Pirie W.L., Broihahn M.A. International Financial Statement Analysis, 2015, $1072 \mathrm{p}$.

2. Demirel E., Atakisi A., Atmaca M. Financial and economic factors affecting debt ratio and ROE; ISE tourism firms case. European Journal of Scientific Research, 2011. 61(3), 458-466.

3. Raifeld A., Gurfinkel M., Rao R., Xi H., Saxena S. An Analysis of the Food and Beverage Industry, 2004. URL: people.stern.nyu.edu/adamodar/pdfiles/cfprojs/food.pdf.

4. EU-MERCl: Analysis of Food and Beverage sector in different Countries. URL: http: .www.eumerci-portal.eu/documents/20182/38527/10+-+Other+countries.pdf.

5. International Journal of Economics and Financial Issues, 2017, 7(3), 537-541. URL: http: .dergipark.gov.tr/download/article-file/365425.

6. Méndez O.A., Castro L.B., Gómez J.G. Qualitative and quantitative analysis of Nestlé, 2010.

URL:http:

.diposit.ub.edu/dspace/bitstream/2445/46834/1/Qualitative\%20and\%20Quantitative\%20Analysis\%20 of\%20Nestl\%C3\%A9.pdf.

7. Official cite of the Nestle company. URL: https: www.nestle.ua.

8. Official cite of The Nielsen Company. URL: https: www.nielsen.com

9. The portal for statistics. URL: https: www.statista.com.

10. World Bank Open Data. URL: https: data.worldbank.org.

11. Комаріст К.А., Доценко О.В., Луценко Р.Р., Іванкіна О.В. Інвестиційний аналіз найбільшого в світі виробника продуктів харчування. Цифрова економіка: моделі та методи аналізу: зб. тез доп. міжнар. наук.-практ. конф., м. Харків, 19-20 квітня 2019 р. Харків, 2019. С. 166-168.

12. BCG: How Big Consumer Companies Can Fight Back. URL: https: .www.bcg.com/publications/2017/strategy-products-how-big-consumer-companies-can-fight-back.aspx. 